\title{
A Comparison between the Use of Nominalization in Medical Papers by English and Iranian Writers
}

\author{
Ali Mahbudi \\ Paramedical school, Shiraz University of Medical Sciences, Shiraz, Iran \\ Ladan Mahbudi \\ Fars Research and Science University, Iran \\ Ehya Amalsaleh (Corresponding Author) \\ Paramedical School, Shiraz University of Medical Sciences, Shiraz, Iran \\ E-mail: asalehe@yahoo.com
}

Received: 01-03-2014

Accepted: 08-06-2014

Published: 01-11-2014

doi:10.7575/aiac.ijalel.v.3n.6p.1

URL: http://dx.doi.org/10.7575/aiac.ijalel.v.3n.6p.1

\begin{abstract}
A prominent feature of formal writing, particularly in the field of science and technology, is the use of nominalization. Scientific writings, including medical writings, are expected to observe formality, precision, lack of ambiguity and concentration of highly technical terms. In such genres, the use of nominalization, affecting the lexical density of the text, plays a key role. In this connection, the purpose of this study was to compare the use of nominalization and the level of lexical density in medical academic articles written by native English writers and their Iranian counterparts based on the theory of grammatical metaphor proposed by Halliday (1985).

To this end, the abstract section of 20 authentic English medical articles written by native English writers and 20 abstracts written by Iranian authors, drawn from highly influential medical journals, were selected. These abstracts were analyzed and compared based on the frequency of nominalization used and the level of lexical density in them. The findings revealed that Iranian writers used less nominalization in their writings.
\end{abstract}

Keywords: Grammatical metaphor, Nominalization, Medical writing, Lexical density

\section{Introduction}

Owing to the importance of scientific writings, in general, and medical writings, in particular, in sharing the findings of their studies, the present work intends to focus on nominalization used in medical writing to communicate with the target audience. Scientific writing, as pinpointed by scholars ( namely, Galve (1998 and Biber, \& Gray, 2010)), follows a different structure, compared with the spoken version. To Galve, one important feature of the written scientific register is the use of noun phrases or nominalizations. He further argues that these nominal groups, which are very common in English medical journal texts, are not static. They are, instead, dynamic resources enabling the representation of shared semantic components in different ways. As systemic functional linguistics views nominalizations one of the prominent factors frequently used in formal scientific texts, this study is to compare and contrast this feature in medical papers by English and Iranian scholars.

\section{1 Systematic Functional Linguistics}

Languages can be viewed from different perspectives. A prominent viewpoint by which languages are analyzed and studied is Systemic Functional Linguistics (Halliday, 1985, Halliday \& Matthiessen, 2004). This trend treats language as a semantic configuration of meanings that are typically associated with a particular context. In other words, language cannot be separated from either its speaker or its context.

\subsection{Metafunctions of language}

Systemic functional linguistics is a functional theory of language in which language is viewed in terms of how it functions in reality, in our real life. In other words, the basic question for studying language in this theory is how language helps us to convey our intentions the way we do. Halliday (1985), the founder of the theory, interprets this functioning of language in terms of three metafunctions: ideational, interpersonal, and textual. The whole model of systemic functional linguistics is based on the relationship and interaction between these three metafunctions. The ideational metafunction of language deals with language as representation. In other words, it focuses on the role of language in representing and shaping reality (Taverniers, 2004; Briones, et al., 2003). The interpersonal metafunction views language as interaction. The textual metafunction is concerned with the textual organization of the language, i.e. discourse. The relationship and interaction between these three metafunctions is the basis of the whole model of systemic functional linguistics (Thompson, 1996). Each of these metafunctional representations of language can be 
expressed through metaphorical expressions, introduced by Halliday (1985). Hence, we may have ideational metaphors as well as those of interpersonal and textual.

\subsection{Grammatical Metaphor}

\subsubsection{Metaphor}

The word metaphor is derived from the Greek meta-, which means "beyond" and pherein, which means "carry". Therefore, metaphor is a kind of movement from one thing to another; that is, one thing is carried beyond itself to something else which is somehow different (Taverniers, 2004).

There are two types of metaphor, namely lexical and grammatical. The former is a feature belonging to the vocabulary of a language. In fact, lexemes express new, metaphorical meanings (Taverniers, 2004). The following examples show how some words are used metaphorically:

The sky is crying./the face of a watch/The noise gave me a headache.

Grammatical metaphors refer to grammatical forms or grammatical means of expression (Briones, et al., 2003). Generally, we realize people, places and things by means of nouns, actions by verbs and circumstances by prepositional phrases and adverbs. However, all meanings may have more than one way of realization. For example, in written language, particularly in the language of science the realizations of the semantic functions of the clause are not typical but marked. This realization forms grammatical metaphor (GM). A GM is "the process whereby meanings are multiplycoded at the level of grammar" (Martin, 1993b:230). Thus grammatical metaphor is a substitution of one grammatical structure by another, e.g. "his discovery" instead of "he discovered". In this example, the lexical items change in function but not in meaning. Grammatical metaphor involves a type of metaphorical movement. For example, a clause changes into a noun phrase or an adverb changes into an adjective. In contrast to lexical metaphor, grammatical metaphor is, in fact, an alternative grammatical resource in language expressing the same meaning in another form or structure. Note the following examples:

\section{We could not investigate the ribosomes until the EM was developed.}

1a. The investigation of ribosomes had to await the development of the EM.

\subsection{Nominalization}

Halliday (1998) maintains that a clause is the most common form by which a process is normally expressed. However, this process can metaphorically be expressed by means of a noun phrase. In fact, the grammar's potential for nominalizing, turning verbs and adjectives into nouns, is exploited to transcategorize, i.e. to derive one grammatical category from another (Randaccio, 2004). Nominalization is the most common type of grammatical metaphor used in language, particularly in the language of science. Scientific discourse is a highly nominalized discourse because nominalization can be used for categorization and taxonomic organization. This grammatical metaphor can be used for reasoning and logical progression (Randaccio, 2004). According to functional linguists, nominalization is one of the primary means of creating grammatical metaphor which affects the expression of written English. The use of nominalization in scientific articles helps to condense information. Thus, in addition to saving the writer from repeating long descriptions, this linguistic device reduces longer phrasal constructions, making scientific language more compact, more functional. Nominalizations produce a greater concentration of the experiential meaning and a smaller incidence of interpersonal elements, such as personal pronouns and modal verbs, thus presenting information in a less personalized way (Taverniers, 2004 ). Furthermore, nominalization contributes to the formality of the text. This, in turn, leads to the text lexical density, as claimed by Ure (1977). Hence, nominalization and lexical density both affect the formality of the text to a great degree. Consider these examples:

The association between spontaneous hypoglycemia and mortality was eliminated after adjustment for comorbidities.

In this sentence, the process 'associate' becomes a thing 'association'. The verb associate is nominalized.

These findings highlight that clarification is needed to guide choice of antithrombotic therapy for patients with both atrial fibrillation and acute myocardial infarction.

In this example, the processes 'clarify' and 'choose' become things 'clarification' and 'choice'. The verbs 'clarify' and 'choose' are nominalized.

A subtype of scientific discourse is the language used in medical texts and articles. As the use of nominalization varies in different types of scientific discourse (i.e., engineering, physics.), this study intends to investigate the use of the nominalization as the subcategory of the grammatical metaphor and lexical density in the abstract sections of medical articles written by native English writers and their Persian counterparts.

\section{Review of the literature}

The studies on the use of grammatical metaphors in scientific discourse have come to interesting conclusions in the relevant literature. Gotti, M. (2002) analyzed a sentence taken from Newton's Treatise on Opticks: "Now those colors argue a diverging and separation of the heterogeneous rays from one another by means of their unequal refractions." and concluded that the better flow of discourse and inclusion of more information in this sentence is due to the process of nominalization. In this regard, Randaccio, M. (2004) in her analysis of scientific discourse comes to the conclusion that the concept of grammatical metaphor is not a simple rewording of another form or structure. She maintains that when there is a shift in the metaphoric mode, grammar, in fact, creates new meanings. She continues that a grammatical 
metaphor gets into a text instantly for immediate requirement of a discourse. This grammatical metaphor may then become a systematic construct, i.e. something for the long-term requirement of the discourse. Furthermore, Vu Thi, M. (2012) in his MA thesis on the use of grammatical metaphor in English pharmaceutical discourse, finds out that English pharmaceutical discourse authors used grammatical metaphors in a large proportion of papers with a high frequency. In fact, $95.45 \%$ of the clauses analyzed by the researcher has shown evidence of grammatical metaphor. The researcher comes to the conclusion that English pharmaceutical authors mostly make use of ideational grammatical metaphor. David Banks (2005) has also explored the origin of nominalization in scientific writings. He maintains that although nominalization is a common feature of scientific style nowadays, it has not always been the case. He further argues that different scientific branches, e.g. biological and physical sciences, present dissimilar characteristics in their use of nominalization. He attributes this difference in the increased use of nominalizations between various branches of science to their contexts. However, he finds that the trend is towards an increased use of nominalizations in scientific discourse. Susana Briones and her colleagues (2003) in their analysis of grammatical metaphors in scientific English maintain that language and science go together and when one learns science, they create a language to codify, extend and transmit scientific knowledge. Finally, they argue that nominalization in general and grammatical metaphors in particular are far from being arbitrary features. They are, in fact, essential resources through which scientific discourse is constructed. In another comparative study by GAO Wenyan (2012) on the use of nominalization in medical papers by native speakers of English and Chinese writers of English medical papers, the researcher notices that Chinese writers do not use nominalization as frequently as native English writers. Investigating the frequency of the use of nominalization in medical papers and examining the lexical density in those papers, Wenyan (ibid) comes to the conclusion that metaphorical expression is more characteristic of the language of native English speakers than those with English as a second or foreign language like Chinese. The definition of lexical density given by Halliday is "the number of lexical items, as a proportion of the number of running words" (Halliday1985:64). Yvonne Tsai (2013) in a study concerning the analysis of patent abstracts mentions that lexical density can be used as an indicator of text type by measuring the number of content words used in a text. It is concluded that written texts are more formal than spoken texts, and thus it is reasonable to assume that written texts are lexically denser than spoken texts. Technical texts and especially the science texts are texts with a heavy information load. For this reason, the lexical densities of scientific texts may be considerably higher, depending on how lexical items are distributed in the grammatical structure.

\section{Method}

As the purpose of the study was to compare and investigate the use of nominalization and lexical density in medical papers produced by native English writers and their Persian counterparts, the abstract sections of 40 authentic articles in the field of medicine, drawn from influential journals, were chosen for analysis. Twenty of the English articles were written by native English authors and 20 by Persian writers. The abstracts were selected through a random selection written in 2010 through 2013. Thus, all of the abstracts had an equal and independent chance of being selected. The medical journals from which the native English speakers' abstracts were selected were The American Journal of Medicine (2010-2013) and British Journal of Medicine and Medical Research (2010-2013) and the journal from which the abstracts written by Persian authors were selected was Iranian Red Crescent Medical Journal (2010-2013).

The reason why the abstract section was chosen was that this part of any article contains the most compact information. The abstract, in fact, is the densest section of any article, so the use of nominalization in this part is more likely.

First, the frequency of the occurrence of nominalization and level of lexical density in each text were assessed. The frequency of nominalization was obtained through the division of nominalization by the total words in the whole text. A frequency of $1 / 13$ for example means that nominalization occurs on average once every 13 words of the text. This method has already been used by researchers for this purpose (Wenyan, 2012). Lexical density was measured by the number of lexical items divided by the number of ranking clauses. Lexical density isa matter of degree, i.e., it is meaningful when compared with lexical density in another text. This procedure was followed for all medical papers written by native English and Persian writers. The frequency of the occurrence of the nominalization and lexical density for the native English writers was then compared with that for Persian writers, both qualitatively and quantitatively. Some examples of lexical density are as follows:

$\underline{1 \text { a: Decreases }}$ of TC, LDL and TG may be related to tomato antioxidant effect. This course in human required more investigations.

In these sentences, the nouns 'decreases' and 'investigation' derived from the verbs 'decrease' and 'investigate'.

(Lexical density $=4.5$; 9 lexical items and 2 ranking clause)

The above sentence would be written as follows if the writer used the congruent version (i.e., the version in which grammatical metaphors, and hence nominalization are absent.

$1 \mathrm{~b}$ : If TC, LDL and TG decrease, this may be related to tomato antioxidant effect. Scientists should investigate this course in human.

(Lexical density $=3 ; 9$ lexical items and 3 ranking clauses)

In the above example, the lexical density of $1 \mathrm{a}$ is higher than $1 \mathrm{~b}$. Therefore, example $1 \mathrm{a}$ is a more formal sentence. 
In the sentence above the verbs 'supplement' and 'concentrate' are changed to nouns supplementation and concentration; in other words, they are nominalized.

(Lexical density $=10 ; 10$ lexical items and 1 ranking clauses)

Over the past decades, a considerable interest has developed in the identification of genes that contribute to the etiology of orofacial cleft.

In this example the verb 'identify' has been changed to noun, i.e., it is nominalized.

(Lexical density $=5.5$; 11 lexical items and 2 ranking clauses)

\section{Results}

\subsection{The Frequency of the occurrence of Nominalization in Each Text}

To obtain the frequency of nominalization, we need to divide the number of nominalization by the number of total words in the whole text. Table 1 displays the frequency of nominalization used by the native English writers in the field of medicine. As we can see, English native writers tend to make use of nominalizations frequently in their medical articles. Moreover, Table 2 displays the trend of using nominalizations by Persian writes of medical articles.

Table 1. Frequency of Nominalization in AB (abstract section) by native English Writers

\begin{tabular}{lllllllllll}
\hline & $\mathrm{N} 1$ & $\mathrm{~N} 2$ & $\mathrm{~N} 3$ & $\mathrm{~N} 4$ & $\mathrm{~N} 5$ & $\mathrm{~N} 6$ & $\mathrm{~N} 7$ & $\mathrm{~N} 8$ & $\mathrm{~N} 9$ & N10 \\
\hline Nominalization & 18 & 20 & 24 & 23 & 24 & 38 & 21 & 26 & 37 & 21 \\
Total words & 249 & 276 & 165 & 165 & 251 & 240 & 278 & 251 & 347 & 237 \\
Frequency & $1 / 13$ & $1 / 13$ & $1 / 6$ & $1 / 7$ & $1 / 10$ & $1 / 6$ & $1 / 13$ & $1 / 9$ & $1 / 9$ & $1 / 11$ \\
\hline & & & & & & & & & & \\
\hline & $\mathrm{N} 11$ & $\mathrm{~N} 12$ & $\mathrm{~N} 13$ & $\mathrm{~N} 14$ & $\mathrm{~N} 15$ & $\mathrm{~N} 16$ & $\mathrm{~N} 17$ & $\mathrm{~N} 18$ & $\mathrm{~N} 19$ & $\mathrm{~N} 20$ \\
\hline Nominalization & 14 & 18 & 28 & 29 & 28 & 21 & 18 & 34 & 25 & 35 \\
Total words & 248 & 249 & 280 & 284 & 259 & 230 & 213 & 342 & 172 & 234 \\
Frequency & $1 / 13$ & $1 / 13$ & $1 / 10$ & $1 / 9$ & $1 / 9$ & $1 / 10$ & $1 / 11$ & $1 / 10$ & $1 / 6$ & $1 / 6$ \\
\hline
\end{tabular}

Table 2. Frequency of Nominalization in AB (abstract section) by Iranian Writers

\begin{tabular}{lllllllllll}
\hline & Ir 1 & Ir2 & Ir3 & Ir4 & Ir5 & Ir6 & Ir7 & Ir8 & Ir9 & Ir10 \\
\hline nominalization & 5 & 11 & 25 & 10 & 6 & 10 & 13 & 10 & 11 & 9 \\
Total words & 116 & 221 & 264 & 169 & 253 & 178 & 220 & 224 & 179 & 165 \\
frequency & $1 / 23$ & $1 / 20$ & $1 / 10$ & $1 / 16$ & $1 / 42$ & $1 / 17$ & $1 / 16$ & $1 / 22$ & $1 / 16$ & $1 / 18$ \\
\hline \multicolumn{1}{r}{} & & & & & & & & & \\
\hline & Ir11 & Ir12 & Ir13 & Ir14 & Ir15 & Ir16 & Ir17 & $\operatorname{Ir} 18$ & $\operatorname{Ir} 19$ & $\operatorname{Ir} 20$ \\
\hline Nominalization & 11 & 11 & 12 & 15 & 15 & 6 & 16 & 11 & 12 & 14 \\
Total words & 227 & 163 & 228 & 243 & 214 & 161 & 285 & 202 & 232 & 198 \\
frequency & $1 / 20$ & $1 / 14$ & $1 / 19$ & $1 / 16$ & $1 / 14$ & $1 / 26$ & $1 / 16$ & $1 / 18$ & $1 / 19$ & $1 / 14$ \\
\hline
\end{tabular}

As the above Table shows, unlike native speakers of English, the Persian counterparts use such forms very sparsely. Tables 3 and 4 display lexical density in the medical articles written by English native speakers and their Persian counterparts, respectively. A comparison of these Tables reveals the higher level of lexical density used by the former than that by the latter.

Table 3. Lexical density in AS (abstract section) written by native English writers

\begin{tabular}{lllllllllll}
\hline & $\mathrm{N} 1$ & $\mathrm{~N} 2$ & $\mathrm{~N} 3$ & $\mathrm{~N} 4$ & $\mathrm{~N} 5$ & $\mathrm{~N} 6$ & $\mathrm{~N} 7$ & $\mathrm{~N} 8$ & $\mathrm{~N} 9$ & $\mathrm{~N} 10$ \\
\hline $\begin{array}{l}\text { Total } \\
\text { words }\end{array}$ & 249 & 276 & 165 & 165 & 251 & 240 & 278 & 251 & 347 & 237 \\
$\begin{array}{l}\text { Lexical } \\
\text { items }\end{array}$ & 129 & 144 & 89 & 102 & 138 & 142 & 140 & 154 & 171 & 139 \\
$\begin{array}{l}\text { Ranking } \\
\text { clause }\end{array}$ & 11 & 11 & 8 & 5 & 11 & 10 & 10 & 12 & 16 & 10 \\
$\begin{array}{l}\text { Lexical } \\
\text { density }\end{array}$ & 11.7 & 13 & 11.1 & 20.4 & 12.5 & 14.2 & 14 & 12.8 & 10.6 & 13.9 \\
\hline
\end{tabular}




\begin{tabular}{lcccccccccc}
\hline & N11 & N12 & N13 & N14 & N15 & N16 & N17 & N18 & N19 & N20 \\
\hline $\begin{array}{l}\text { Total } \\
\text { words }\end{array}$ & 248 & 249 & 280 & 284 & 259 & 230 & 213 & 342 & 172 & 234 \\
$\begin{array}{l}\text { Lexical } \\
\begin{array}{l}\text { items } \\
\text { Ranking }\end{array}\end{array}$ & 124 & 150 & 183 & 188 & 120 & 130 & 115 & 224 & 119 & 141 \\
$\begin{array}{l}\text { clause } \\
\begin{array}{l}\text { Lexical } \\
\text { density }\end{array}\end{array}$ & 12.4 & 11 & 14 & 17 & 9 & 11 & 8 & 18 & 9 & 8 \\
\hline
\end{tabular}

Table 4. Lexical density in AS (abstract section) written by Iranian writers

\begin{tabular}{lllllllllll}
\hline & Ir1 & Ir2 & Ir3 & Ir4 & Ir5 & Ir6 & Ir7 & Ir8 & Ir9 & Ir10 \\
\hline $\begin{array}{l}\text { Total } \\
\text { words }\end{array}$ & 116 & 221 & 264 & 169 & 253 & 178 & 220 & 224 & 179 & 165 \\
$\begin{array}{l}\text { Lexical } \\
\text { items }\end{array}$ & 62 & 127 & 141 & 103 & 130 & 106 & 134 & 127 & 95 & 62 \\
$\begin{array}{l}\text { Ranking } \\
\text { clause }\end{array}$ & 7 & 12 & 14 & 10 & 14 & 11 & 14 & 12 & 9 & 6 \\
$\begin{array}{l}\text { Lexical } \\
\text { density }\end{array}$ & 8.8 & 10.5 & 10.0 & 10.3 & 9.2 & 9.6 & 9.5 & 10.5 & 10.5 & 10.3 \\
\hline
\end{tabular}

\begin{tabular}{lcccccccccc}
\hline & Ir11 & $\operatorname{Ir} 12$ & $\operatorname{Ir} 13$ & $\operatorname{Ir} 14$ & $\operatorname{Ir} 15$ & $\operatorname{Ir} 16$ & $\operatorname{Ir} 17$ & $\operatorname{Ir} 18$ & $\operatorname{Ir} 19$ & $\operatorname{Ir} 20$ \\
\hline $\begin{array}{l}\text { Total } \\
\text { words }\end{array}$ & 227 & 163 & 228 & 243 & 214 & 161 & 285 & 202 & 232 & 198 \\
$\begin{array}{l}\text { Lexical } \\
\text { items }\end{array}$ & 107 & 78 & 110 & 115 & 127 & 84 & 171 & 128 & 134 & 98 \\
$\begin{array}{l}\text { Ranking } \\
\text { clause }\end{array}$ & 13 & 8 & 12 & 11 & 13 & 9 & 16 & 12 & 13 & 10 \\
$\begin{array}{l}\text { Lexical } \\
\text { density }\end{array}$ & 8 & 9.7 & 9 & 10.4 & 9.7 & 9 & 10.6 & 10.6 & 10 & 9 \\
\hline
\end{tabular}

A comparison of the Tables 3 and 4 reveals the higher level of lexical density used by the former than that by the latter.

\section{Discussion}

As the purpose of this study was to compare the use of nominalizations and level lexical density used in medical articles by English native speakers and their Persian counterparts, the abstract sections of 40 English articles (20 written by English writers and 20 by Persian writes) were selected for data analysis. The analysis showed the more frequent use of such structures with higher level of lexical density by English writers. The findings of our study are in compliance with what Wenyan (2012) has found. In his study, Wenyyan found out thatin spite of the crucial role of nominalization in the cohesion and coherence of medical papers and the improvement of formality and the removal of ambiguity, Chinese academic writers in the field of medicine did not use nominalizations as frequently as native English writers. Our study showed that the Iranian academic writers in the field of medicine used fewer cases of nominalization than their native English counterparts. As Wenyan argues, it seems that the use of metaphorical expressions is more typical of the language of native English speakers than those with English as a second or foreign language like the Chinese or Persian academics. This might be due to the fact these learners are not as fluent and competent in English as the native speakers. In line with this, Thompson (2000) argues that as nominalization plays an important role in encapsulating the information, writers can contain a large amount of information in a comparatively small place through nominalization. Those who have a good command of a language can do this more easily and more conveniently. The finding may suggest that English writers tended to use more cases of nominalizations in their articles. Likewise, Vu Thi Mau (2012) has found that the use of nominalization is a typical feature of pharmaceutical discourse produced by English writers. As is shown in Tables 3 and 4, the abstract sections by Iranian writers have lower lexical density than those of native academic writers. This is mostly due to the fewer cases of nominalizations used by Iranian writers. In other words, in medical articles written by Iranian authors, there are more ranking clauses to share the lexical items. In fact, when one masters the language, he/she can combine two or more grammatical structures in one nominal group. That is why we can find a far higher density of lexical items in the written language by natives. As we have found, the second/foreign language writers who do not have a good command of the language do not make use of this strategy. Generally speaking, in formal written language, there are fewer clauses; in other words, two or more grammatical structures are combined in one nominal group. Halliday (1998) argues that the written language is typically more complex because it is lexically dense. This notion reveals the fact that lexical items are found at a far higher density in the written language 
than in the spoken language. Thus, we can conclude that scientific writings have the high formality because of the high level of lexical density and nominalization.

\section{Conclusion}

As our findings showed Iranian researchers used nominalization less frequently than their English counterparts. This may be responsible for the difference found between natives' and non-natives' writing. That is, one feature affecting the writing of non-natives sounds odd is the absence of or sparse use of nominalization in their writing. This necessitates a revision of the academic writing courses to medical students and the inclusion of genre analysis of medical papers with particular emphasis on their grammatical metaphor in the form of nominalization.

\section{References}

Banks, D. (2005). On the historical origins of nominalized process in scientific texts. English for SpecificPurposes, 24 (3), 347-357.

Biber, D., \& Gray, B. (2010). Challenging stereotypes about academic writing: complexity, elaboration, explicitness. Journal of English for Academic Purposes (9), 2-20.

Briones, S., Fortuny, L. \& Sastre, S. (2003). Grammatical metaphors in scientific English. The ESPecialist, Vol. 24( 2), 131-142.

Galve, I.G. (1998). The textual interplay of grammatical metaphor on the nominalizations occurring in written medical English. Journal of Pragmatics (30), 363-385.

Gotti, M. (2002). The Development of English as a Language for specialized purposes. In G. Cortese and P. Riley (eds.) Domain-specific English. textual practices across communities and classrooms. New York and Oxford: Peter Lang, $65-$ 86.

Halliday, M.A.K. (1985). Introduction to functional grammar. London: Arnold.

Halliday, M.A.K. (1998). Things and relations. In: J.R. Martin \& Robert Veel (eds.) Reading science, critical and functional perspectives on Discourses of Science. London: Routledge. 185-235.

Halliday, M. A. K., Matthiessen, C. (2004). An introduction to functional grammar ( $3^{\text {rd }}$ eds.), London: Arnold. Maclean, J. (1975). English in basic medical sciences (English in Focus). OUP.

Randaccio, M. (2004). Language change in scientific discourse. JCOM 3(2). http://jcom.sissa.it/archive/03/02/A030201/jcom0302\%282004\%29A01.pdf

Taverniers, M. (2004). Grammatical metaphors in English. Moderna Sprak 98 (1), 17-26.

Thompson, G. (1996). Introducing functional grammar. London: Arnold.

Thompson, G. (2000). Introducing functional grammar. Beijing: Foreign Language Teaching and Research Press.

Ure, J., \& Ellis, J. (1977). Register in descriptive linguistics and linguistic sociology. In O. Uribe-Villas (ed.). Issues in Sociolinguistics. The Hague: Mouton.

Vu Thi, M. (2012). Grammatical metaphor in English pharmaceutical discourse. Unpublished MA thesis.

Wenyan, G. (2012). Nominalization in medical papers: A comparative study. Studies in Literature and Language, 4(1), pp. 86-93. 